CHAPTER THIRTEEN

\title{
CRIMES AGAINST HUMANITY
}

\section{Criminalization in International Criminal LaW}

The term 'crimes against humanity' was first formulated in the Declaration of 1915 concerning the genocide of Armenian by the Turkish government. It was later reformulated in the Charter of the International Military Tribunal in Nuremberg for the prosecution and punishment of Major War Criminals. ${ }^{1}$ Crimes against humanity were defined as 'murder, extermination, enslavement, deportation, and other inhumane acts committed against any civilian population, before or during the war; or persecutions on political, racial, or religious grounds in the execution of or in connection with any crime within the jurisdiction of the Tribunal, whether or not in violation of the domestic law of the country where perpetrated.' ${ }^{2}$ This definition has, rapidly, been developed and enlarged in the system of international criminal law by the establishment of the United Nations Organization and the formulation of a number of international criminal conventions applicable to crimes against humanity. Some of the most recognised instruments which have been ratified by a great number of states include, the Convention on Prevention and Punishment of the Crime of Genocide, 1948, the International Convention on the Suppression and Punishment of the Crime of Apartheid, 1973, Geneva Convention for the Amelioration of the Condition of the Wounded and Sick in Armed Forces in the Field, 12 August 1949, Geneva Convention for the Amelioration of the Condition of Wounded, Sick and Shipwrecked Members of Armed Forces at Sea, 12 August 1949, Geneva Convention Relative to the Treatment of Prisoners of War, 12 August 1949, Geneva Convention Relative to the Protection of Civilian Persons in Time of War, 12 August 1949, the Geneva Protocol I Additional to the Geneva Conventions of 12 August 1949, and Relating to the Protection

\footnotetext{
${ }^{1}$ Malekian, International Criminal Law, vol. I, p. 267.

2 Article 6 (c) of the Charter of the International Military Tribunal annexed to the London Agreement of 8 August 1945.
}

This is an open access chapter distributed under the terms of the CC-BY-NC License. 
of Victims of International Armed Conflicts, 12 December 1977 and the Geneva Protocol II Additional to the Geneva Conventions of 12 August 1949, and Relating to the Protection of Victims of Non-International Armed Conflicts, 12 December 1977 and a number of conventions relating to the crime of slavery. ${ }^{3}$ All these conventions have formulated provisions recognizing the commission of certain acts in both war and peacetime as constituting crimes against humanity. This recognition is regardless of the race, colour, national or ethnic origin of an individual or group. These provisions have even been extended within the Statute of the International Tribunal for the Prosecution of Persons Responsible for Serious Violations of International Humanitarian Law Committed in the Territory of the Former Yugoslavia (ICTY) and the Statute of the International Criminal Tribunal for the Prosecution of Persons Responsible for Genocide and Other Serious Violations of International Humanitarian Law Committed in the Territory of Rwanda and Rwandan Citizens Responsible for Genocide and Other Such Violations Committed in the Territory of Neighbouring States (ICTR). They have also been strengthened and consolidated within the Statute of the permanent International Criminal Court (ICC) in 1998. The Statute of the ICC is one of the most authoritative legislations governing the recognition of crimes against humanity in international criminal law.

\section{Criminalization in \\ ISLAMic INTERNATIONAL CRIMINAL LAW}

In Islamic international criminal law it is not necessarily the acceptance of certain regulations and the legislation of certain rules within the domestic and the international criminal systems which identifies which acts do and which acts do not constitute a crime. It is the effect and basic elements of the natural or moral law which prohibits and criminalizes given international criminal conduct. ${ }^{4}$

One must not forget the fact that an individual under Islamic law is recognised as an integral part of the human community and from a more far reaching aspect, an integral part of a universal human life. This

\footnotetext{
${ }^{3}$ For further analysis and discussions see, generally, Malekian, International Criminal Law, vols. I and II.

4 The term "natural law" is also used as moral law. This means God's eternal law, revealed law in the Old Testament, the law of the spiritual commandments or law of the Gospel. Moral law has also developed to express civil law too.
} 
means that injury to a person or discrimination between two persons is considered a crime against the entire international human society. However, the practice is different in the Muslim countries.

It must therefore be emphasised that the provisions regulated within the content of conventions applicable to crimes against humanity in international criminal law are not, regarding Islamic international criminal law, innovative and consequently do not contradict the provisions of Islamic law or the provisions of Islamic international criminal law. For example, the Nuremberg Tribunal recognised murder and the extermination of civilians as constituting crimes against humanity. Islamic international criminal law prohibited the murder and mass killing of civilians long ago and identified such crimes as against the fundamental principles of divine law. The same is true in the case of deporting those who do not take part in actual fighting, even though they have other religions, political and ethnical origins. ${ }^{5}$ Islamic international criminal law, like the system of international criminal law, criminalizes the extermination and murder of individuals. The practice of deporting individuals (for whatever reason) constitutes crimes against humanity once the practice has occurred. Islamic international criminal law essentially prohibits the persecution of individuals on religious, racial and political grounds.

Accordingly all these acts may constitute crimes regardless of whether or not an individual, group or government which has committed such crimes was aware of their criminalization under Islamic international criminal law. This is because (according to Islamic theory) it is not the awareness and information about the criminalization of an act which prevents the commission of related criminal conduct. Rather, it is the nature and the ill characterization of an act which provides the necessary information as to whether it constitutes a criminal conduct in accordance with the principles of legality. Ignorance and/or negligence concerning the law or the order of the law do not prevent the prosecution and punishment of a person who has committed crimes against humanity. Thus, in the case of committing a crime by a person, he/she cannot, due to the plea of non-awareness of the nature of criminality of certain acts, escape from the consequences of the criminal conduct. The system of Islamic international criminal law has, in other words, a very high degree of moral force, while this is almost lacking in the system of international criminal law. The former not only bases its legal sanctions on the principle

\footnotetext{
${ }^{5}$ See part two, chapter on War Crimes.
} 
of legality but also on the natural and moral wrong of criminal conduct, while the latter on the recognition of the system by each individual state. ${ }^{6}$ This means that the criminalization of the given conduct in the system of international criminal law depends on each individual state's decision and whether or not they sign or ratify relevant international criminal conventions. In contrast, the law or obligations are already fixed under Islamic international criminal law and do not need to be ratified. Thus, violations of the system of international criminal law by Islamic leaders have two types of characteristics. These are violations of international criminal law and Islamic international criminal law as a whole. For instance, the Omar Hassan Ahmad al-Bashir case illustrates the position.

The criminalization of a given conduct in Islamic international criminal law therefore has a legal characterization which cannot be ignored and deleted by way of interpretation; this can only be accomplished through the humiliation and monopolization of legal and moral power. Thus, when one speaks of the criminalization of apartheid and discrimination under Islamic international criminal law, one does not need to decide whether the state in which such activities are carried out is Muslim or non-Muslim. This is because in Islamic law it is the spirit of human beings which is identified with dignity and not necessarily the system of law. ${ }^{7}$ It must, of course, be emphasised that the principle of legality has long been revealed in the system of Islamic international criminal law. ${ }^{8}$ The system is for that reason relevant when one deals with the types of crimes against humanity committed during the Second World War, the Vietnam War, in the former Yugoslavia and Rwanda. The crimes committed in the relevant wars create the accountability of the accused persons and call upon their punishability. This is also true in the case of other accused persons under the provisions of the ICC. This is because the vocabulary of the ICC regarding crimes against humanity overlaps with the provisions of Islamic international criminal law in war or peacetime.

\section{Islamic Elements of Crimes against Humanity}

The system of Islamic international criminal law as the system of international criminal law recognises certain elements for the recognition

\footnotetext{
${ }^{6}$ For the principle of legality in Islamic international criminal law see chapter two sub-section 6.2.

7 See, generally, chapter two.

${ }^{8}$ Moreover, subjects in Islamic law are not authorized to codify the law.
} 
of crimes against humanity. This means that in order for an act to be recognised as crimes against humanity in Islamic law, certain elements must exist. Some of the most important elements of this law are:

\subsection{Wisdom of Committing a Wrongful Conduct}

The system of Islamic international criminal law like the system of international criminal law clearly points out the fact that in order for an act to constitute crimes against humanity, the perpetrator must understand that his/her act is wrong and violates the general principles of Islamic law. Similarly, in the system of international criminal law one of the most significant elements for the recognition of certain acts as crimes against humanity is based on the term "knowledge of the attack". As the system of Islamic international criminal law the term considers the principle of mens rea. This means both systems recognize that one of the primary conditions of the recognition of act as crimes against humanity is the intent to commit an action which is recognised as being wrong within the provisions of both systems. The difference between these two systems is that the Islamic uses the term "knowledge" but the other applies the term "wisdom" which is, in reality, a synonym of the former. This is because the tem "knowledge" speaks about the awareness of a person in committing an offence and the term "wisdom" talks about the necessity of understanding or perception. The term "knowledge" has been defined in both systems in the following ways.

According to Kayishema case in the ICTR:

The perpetrator must knowingly commit crimes against humanity in the sense that he must understand the overall context of his act. Part of what transforms an individual's act(s) into a crime against humanity is the inclusion of the act within a greater dimension of criminal conduct; therefore an accused should be aware of this greater dimension in order to be culpable thereof. Accordingly, actual or constructive knowledge of the broader context of the attack, meaning that the accused must know that his act(s) is part of a widespread or systematic attack on a civilian population and pursuant to some kind of policy or plan, is necessary to satisfy the requisite mens rea element of the accused. This requirement further complements the exclusion from crimes against humanity of isolated acts carried out for purely personal reasons. ${ }^{9}$

\footnotetext{
${ }^{9}$ Kayishema (ICTR-95-1-T), Judgement, 21 May 1999, paras. 133-134.
} 
According to the above definition, the accused cannot therefore escape from his/her criminality by reasoning that he/she had not the knowledge of criminal conduct. Consequently, a specific intent to commit crimes against humanity is seen as a necessary condition. But, a constructive knowledge or an understanding that one is going to commit an offence in international criminal law or unacceptable acts in Islamic international criminal law may in itself be sufficient for the proof of guilt.

\subsection{The Existence of the Principle of Intention}

Whilst both systems of international criminal law speak about knowledge or wisdom, the two interchangeable terms, the term knowledge also contains the principle of intention for the commission of an offence while the term "wisdom" does not necessarily refer to intention. This is because in the system of Islamic international criminal law, the term "wisdom" has the role of proving that one has obtained sufficient information about something or has, in one way or another, been informed of the criminal conduct. In other words, the wisdom or understanding of a person does not necessarily denote the intention. This means that an intention constitutes another part of the term "knowledge" but not necessarily its integral part. Thus, an offence may be committed with a clear intention of a person to commit the act without necessarily proofing that the person had the sufficient knowledge of committing a crime against humanity. In other words, the term "knowledge or wisdom" is seen in both systems of international criminal law, a necessary condition for the recognition of crimes against humanity, it is not a decisive factor in the system of Islamic law. The reason is that the law gives a particular recognition to the principle of mens rea and this implies the intention of a person to commit crimes against a human being without due regard to his/her race, nationality, culture, ethnic origin, religion and language.

\subsection{A Wrongful Conduct}

Another condition for the recognition of crimes against humanity is the existence of a conduct which is recognised, as being wrong, according to the basic sources of Islamic international criminal law. Both systems of international criminal law imply the fact that in order for an act to be recognised as a crime against humanity, it must legally be accepted as an offence. Thus, the jurisprudence of Islamic law bases the concept of crimes against humanity on the principle of de lege lata. The system of international criminal law has, also similar to Islamic law, emphasised 
that certain actions which may constitute crimes against humanity must have been codified within the law. Accordingly, the provisions of categories of international crimes in the Nuremberg Charter, the ICTY, the ICTR, the Sierra Leone Court and the ICC imply this fact. Due to the development of the law of those tribunals and the courts, crimes against humanity inter alia are i) Murder; b) Extermination; c) Enslavement; d) Deportation or forcible transfer of population; e) Imprisonment or other severe deprivation of physical liberty in violation of fundamental rules of international law; f) Torture; g) Rape, sexual slavery, enforced prostitution, forced pregnancy, enforced sterilization, or any other form of sexual violence of comparable gravity; h) Persecution against any identifiable group or collectivity on political, racial, national, ethnic, cultural, religious, gender as defined in paragraph 3 , or other grounds that are universally recognised as impermissible under international law, in connection with any act referred to in this paragraph or any crime within the jurisdiction of the Court; i) Enforced disappearance of persons; j) The crime of apartheid; k) Other inhumane acts of a similar character intentionally causing great suffering, or serious injury to body or to mental or physical health.

Without any hesitancy, acts enumerated in the above also constitute crimes against humanity in Islamic international criminal law and call upon the criminal responsibility of the perpetrator. For instance, due to a generally recognised norm of Islamic law, acts which violate the principles of Islamic law concerning non-violence against the physical or psychological integrity of others, are prohibited and constitute torture. Similarly, apartheid, rape, slave prostitution or forced pregnancy are all prohibited and constitute offences against the personal integrity of man. ${ }^{10}$

\subsection{A Criminal Plan}

The fourth stipulation requires that an act is designed to be carried out against a person or particular minority group. As a general rule, the system of Islamic law prohibits intrigues, conspiracies and trickeries against any person or a particular majority or minority group. This is because the true Islam encourages brotherhood, peace and justice. In Islamic international criminal law, the term "crimes against humanity" refers to specific acts of violence against persons or groups regardless of whether they are Muslims, non-Muslims, citizens or non-citizens of

${ }^{10}$ For the above list of crimes see the relevant chapters. 
the state in which the criminal acts against them have been carried out. Similar principles are also recognised in the system of international criminal law. Accordingly, a crime against humanity refers to acts of violence against a particular group. A single act of violence should not however be recognised as crimes against humanity, as long as the other elements are not present. The reason for this is to avoid recognizing any acts of murder or other similar acts as crimes against humanity.

\subsection{No Policy of Widespread}

One of the predominant principles for the recognition of crimes against humanity in international criminal law is the policy of widespread. This policy has been recognised since the creation of the concept of crimes against humanity in relation to the murder of almost one million Armenians in Turkey in 1915. Since that time, it has become obvious that a single act of violence or isolated acts cannot be recognised as crimes against humanity and may be treated by other regulations. ${ }^{11}$ However, in all circumstances, it is the intention of the perpetrators and the combination of other factors of evidence which denote the recognition of a crime as a crime against humanity. Nonetheless, in Islamic international criminal law it is not a policy of widespread which identifies an offence as a crime against humanity but its illegal nature which goes against the integrity of humankind as a whole. Because, it is a recognised principle of Islamic law that a crime against a person is recognised, as a crime against the generation of mankind simultaneously. This means that for the recognition of crimes against humanity, the condition of widespread has no effective role in the recognition of the criminal act, as along as, the criminal act has occurred with the intention of harming or damaging the victim. In any event, both systems of international criminal law have, more or less, a similar policy for the recognition of crimes against humanity. For instance, acts of Saddam Hussein against the Kurdish population in the early eighties can be acknowledged as crimes against humanity within the regulations of both systems. Similarly, acts of certain Islamic regimes against their population can, also, be recognised as crimes against humanity within the regulations of both systems of international criminal law. This is regardless of the motivation of those fanatical regimes.

11 W.J. Fenrick, 'Should Crimes Against Humanity Replace War Crimes?', 37 (767) Columbia Journal of Transnational Law (1999). 


\subsection{Policy of Systematic}

The term "widespread" has a close relation with the term "systematic", but may not necessarily have the same definition. In the system of international criminal law both terms are used, some times separately and sometimes collectively in order to express the seriousness of a criminal act. The International Criminal Tribunal for Rwanda defines the term "widespread". Accordingly, the term "The concept of widespread' may be defined as massive, frequent, large scale action, carried out collectively with considerable seriousness and directed against a multiplicity of victims." The same Tribunal defines the terms "systematic". ${ }^{12}$ According to this definition, the "'concept of systematic' may be defined as thoroughly organised and following a regular pattern on the basis of a common policy involving substantial public or private resources. There is no requirement that this policy must be adopted formally as the policy of a state. There must however be some kind of preconceived plan or policy."13

Within Islamic international criminal law, similar to that of international criminal law, the concept of systematic refers to organised actions against a particular group. In law and in practice, such actions were prohibited and regarded as a violation of the law of God. However, Islamic law does not put, as does the system of international law, the condition of systematic for the recognition of crimes against humanity. The crime can be committed by any means without any particular need to prove that the action was systematic. However, a systematic or common policy of an action may be helpful for the identification of the crime and assistance to the victim. This means that the concept of crimes against humanity in Islamic international criminal law is not based on the repetition of an act as constituting one of the elements of the recognition of the crime, but, on the substantial value of human beings, the natural or positive privacy of whom is strongly violated.

\subsection{A Wilful Blindness}

A wilful blindness cannot reduce the recognition of crimes against humanity. A wilful blindness is not accepted within the theory of Islamic international criminal law. Similarly, the system of international criminal law rejects the defence of wilful blindness. The term "wilful blindness" refers to a situation in which the accused seeks to keep, himself/herself,

12 Akayesu (Case No. ICTR-96-4-T), Judgment, September 1998, para. 580.

${ }^{13} \mathrm{Id}$. 
away from criminal responsibility for the wrongful conduct. The fact is that he/she has deliberately avoided having the knowledge of certain information and in order to release himself/herself from the suspicion of committing the relevant crime. A clear example is when during a war, one attacks hospitals, schools and other similar public services but claims that he/she did not have any information about the localities and therefore lacked the requisite intent to break certain provisions of the law. Neither Islamic international criminal law, nor the system of international criminal law accepts the defendant theory. The basic argument is that the defendant should have known the result of his/her actions or omissions when committing the crime. For instance, due to the basic idea of Islamic law, religious buildings such as Churches and Mosques are instituted for worship and cannot be a target of attack. Depending on the circumstances of each case, any violation against these institutions may be considered crimes against humanity and war crimes. The reason is that Islamic law, in general, and Islamic international criminal law, in particular, does not allow attacks on religious buildings. One should also see what is permissible and what is not permissible in the Islamic jurisprudence as a whole. In other words, "man must always do what is good, and abstain from what is evil, and take scrupulous care of the intermediary grades of plausible, permissible and disliked." 14 Furthermore, the general idea of Islamic law is based on the promotion and encouragement of awareness and attenuation of blindness.

\section{List of Crimes against Humanity}

The system of international criminal law has, in the Statute of the ICC, provided the most recent list of crimes against humanity which are, without doubt, identical with the concept of crimes against humanity in Islamic international criminal law. This means that both laws have recognised certain actions as crimes against humanity and therefore punishable offences. The concept of crimes against humanity in Islamic international criminal law may therefore be listed as follows:

- killing, murdering, slaying, assassinating a person(s),

- slaughter or extermination of a large or small number of persons,

- imposing slavery conditions upon persons,

- forcible transfer of population by different manners including psy-

${ }^{14}$ Hamidullah, The Muslim Conduct of State, p. 3. 
chological or physical force which ends in the deportation of one group of individuals to other areas,

- restricting the personal integrity of individuals through acts of imprisonment, detention, arrest, seizure, capture or any other methods such as the severe deprivation of physical liberty in violation of the fundamental rules of natural or positive law of the universe,

- torturing different individuals or groups for various cultural, religious, linguistic or other legal or illegal reasons,

- violation of sexual integrity of individuals by different methods including rape and sexual slavery,

- forcible matrimony or marriage

- prostitution of all types,

- pregnancy,

- enforcing different methods of sterilization on men or women with old or new techniques,

- harassment or maltreatment of individuals or groups based on religious, racial, ethnic, cultural or any other reason which demonstrates the specific position of those individuals or groups,

- disappearance of persons as a result of different acts of the perpetrators;

- categories of discrimination based on racial, ethical, religious, cultural, language, political or any other reason which makes discriminated persons different from that of the Muslim population,

- discriminating in one way or another between the gender

- intentionally causing physical or mental health problems to individuals or a particular group. 